\title{
THE ECONOMICS OF NUCLEAR ENERGY: GLOBAL EMPIRICAL ANALYSIS WITH EGYPT AS A CASE STUDY.
}

Karim Badr El-Din Attia Hassanien

The British University in Egypt (BUE) 


\title{
THE ECONOMICS OF NUCLEAR ENERGY: GLOBAL EMPIRICAL
}

\author{
ANALYSIS WITH EGYPT AS A CASE STUDY. \\ Karim Badr El-Din Attia Hassanien ${ }^{1}$ \\ The British University in Egypt (BUE)
}

\begin{abstract}
Purpose: This research paper aims to analyze the global energy market in order to identify the conventional energy sources, the renewable energy source, and the nuclear energy as vehicles for economic development. This requires analyzing the investment capital versus the operation costs in each case.

Design/methodology/approach: The analysis of the data collected supported the choice of Egypt as a case study to represent the economic problem of its low production of electricity energy as compared to both developed countries in general and to other specific developing countries. The analysis represents the interaction between the need of Egypt to increase the production of electricity energy and the need to increase the gross domestic product (GDP) simultaneously.
\end{abstract}

Findings: The data collected at both the global level and at Egypt's level represented the various energy resources at a comparative level. The findings typified the need of Egypt to increase its production of electricity energy to match with its development requirements. This could never be done without the use of nuclear energy to produce electricity energy to serve the various Egyptian economic sectors.

Originality/value: The data collected were sorted and analyzed in a statistical manner to analyze the Egyptian requirement of energy in general and nuclear energy in specific for economic development.

Keywords: Economic Development, Gross domestic product (GDP), Cost of electricity, Environment, Levelized cost of electricity, Economic development, Investment capital, Operation costs, Net benefit, Economics of the power grid, Generation resources, Existing sources, New resources, Renewable resources.

Paper type: Research paper.

\section{Introduction}

During the second half of the twentieth century, the world witnessed several substantial changes. Such crucial changes were evident in the special emphasis given to the issue of development of energy sources and investment. In economics the three main factors of production are labour (human capital), capital (physical capital) and land. Development of human capital and physical

${ }^{1}$ Department of Economics, Faculty of Business Administration, Economics and Political Science (BAEPS), The British University in Egypt (BUE), EGYPT. 
capital in the energy sector became the cornerstone of economic cooperation, and a motive for global political changes as a vehicle for the global flow of funds and investments.

These huge investments were also directed by both economic and political factors. The economic aspect was an ultimate result of the huge industrial development, especially in the developed countries. The political is beyond the analysis in this research paper, but it is still an important component that has a direct impact on the world economic and political stability.

The development of the energy sector shifts any economy to a better, i.e. developed, position. It is a dynamic process that helps poor societies to overcome their economic problems. It is more practical to evaluate the process of development at this stage as a socio-economic process. The economic and the social aspects are of mutual effect and are still integrated. There are several major challenges that need to be considered to provide the socio-economic meaning of development of the energy sector.

The importance of the development of this sector is not only attributed to the development of the industrial sector, but it is still very important for the quality of life for any person in the society. Energy requirement turned to be a daily requirement for lighting, communication, transportation and all aspects of daily life. The absence of these factors is considered to be an ultimate economic and social risk.

According to the International Energy Statistics of the International Energy Data and Analysis, The U.S. Energy Information Administration (EIA)- the U.S. Department of Energy (DOE), 2015, Egypt is ranked as number 25 among other countries in Total Electricity Net Generation in 2012 with an amount of 155 Billion Kilowatt-hours. This is definitely a low level of production if compared to other developed countries and even to some other less developed (developing) countries, such as Saudi Arabia and Ukraine. This ultimately constitute an obstacle to the Egyptian endeavours to attain social and economic development as the biggest Arab economy in terms of population and industrial sector.

This research paper attempt to underline an analysis of current status of energy from a global point of view, especially as related to nuclear power with special emphasizes on Egypt as a case study.

\section{Literature Review}

In fact, when we study the three main elements of this proposed research, we discover that they are related to global energy sources and production on one hand Egypt's energy sources and production on the other hand. This research provides a link between them. Such a link has not been the subject of any 
previous literature, which has been concerned with these elements as separate topics. Very few studies provide indirect link between them, but no previous study has formulated a direct link between them, which constitutes the main research gap. Accordingly, no case study was chosen to provide the missing direct link between these research elements.

Energy is a subject covered by economists, social scientists and socioeconomic researchers. Hoogwijk (2014), ASES (2014), EEA (2006), Doornbosch (2009), and Greenpeace (2007) analysed the various forms of renewable energy and the rapid deployment of Renewable Energy Sources (RES) given by hydropower energy, wind onshore energy, wind offshore energy, solar energy, geothermal energy, and ocean energy.

According to Berndes (2013), Bjornsson (2014), Fellows (2012), Fischer (2010), and Ericsson (2013) when comparing the renewable electricity sources at an international level, it was found that renewable energy sources have the potential to provide several times the current energy supply. Solar power is the biggest renewable energy source, followed by wind energy and then followed ocean energy. North Africa is the richest region of solar power energy. North America is the region with the highest potential of generating wind energy. Europe is not the richest region in terms of a specific type of renewable energy sources, but still it has low cost potential as related to hydropower energy and wind energy. Most other parts of the world have a remarkable potential as related to solar power energy.

On the other hand, Bartle (2012), Dessus (2104), and Lako (2013) stipulated that the global energy is rapidly approaching a transition point with the development of new power generation. This will lead to a huge strain on the existing power grids which might result in blackouts, and brownouts that will require high levels of expenditures to upgrade the existing grids. The only viable solution to tackle such problems is to resort to energy management technologies, advanced energy storage technologies, and demands management techniques. These methods are viable because they can improve the energy storage and delivery efficiency and they are still cost effective techniques. These key aspects are essential for the future development in both developed countries and developing countries, and to advance the structure of the power grids to accelerate the introduction of clean renewable and nuclear energy worldwide. This will help to replace the polluted energy generated from the fusel fuels.

Vries (2007), Hofman (2102), Johansson (2103), Siegfriedsen (2014), and Yamamoto (2010) emphasized in their analysis the importance of sustainable development as related to energy production. The usage and the production of energy from various sources should serve the process of economic development without depriving the future generations from having their own future development. This requires all sectors and companies to preserve the 
sustainability of their own activity as a contribution to the worldwide sustainability. Therefore, all parties dealing in the energy sector must meet their own objectives set by their shareholders, and simultaneously must give special attention to the strategic goals of the global sustainable development, given by considering the impacts of their activities on the environment, the society and the economy as their stakeholders. The international community put recent emphases on providing an international framework for such issue of sustainability. The 1972 Stockholm Summit arrived at a framework for Climate Change (CC) which resulted in the 1988 establishment of an Intergovernmental Panel on Climate Change (IPCC) composed of the World Meteorological Organization (WMO) and the United Nations Environment Program (UNEP) to evaluate all $\mathrm{CC}$ available scientific information to assess its economic, social and environmental aspects. This became the cornerstone of several successive earth summits after the establishment a new global sustainable development model in the Rio Summit in 1992. This new model provides for the three aspects of sustainable development as related to the environmental, social, and economic aspects.

EIA (2013), Bradley (2013), and Younes (2013) verified that although Egypt is nonOPEC (Organization of Petroleum Exporting Countries) energy producer, but still it is an important producer that has the sixth largest proved oil reserves in Africa. Egypt is an observer in the OPEC but still a full member in the OAPEC (Organization of Arab Petroleum Exporting Countries). Also, Egypt has the third largest proved natural gas reserves in Africa. Also, Egypt has the biggest existing hydroelectric power generation in Africa in the Aswan Dam since the end of the 1950s. In the field of renewable energy, Egypt has established wind and solar energy stations. Egypt is still embarking its new nuclear energy projects to generate electricity.

\section{Objectives of the Study}

It is clear from the previous illustration of the literature review that this research paper in its theoretical and empirical framework provides the missing link between the analysis of the current status of energy from a global point of view, especially as related to nuclear power and the relevant position of Egypt as a case study. The field study with its applicable results and recommendations could be considered the first case study in this connection.

The relevant field study was carried out at a global level and in Egypt. This was achieved by identifying, in a precise manner, the main dimensions of the energy generation. Thus, the ultimate objective was to design the proposed framework concerned with achieving development by tackling the possible forms of energy generation that serves the economic development process. This required the provision of recommended solutions to the possible energy generation maximization in a sustainable manner. More specifically, the proposed study carried out the following tasks:

1. Identifying the main parameters of the energy generation resources. 
2. Identifying the main parameters of the energy generation aspects.

3. Identifying the all relevant problems facing the energy generation process.

4. Identifying all the economic and environmental problems attributed to energy generation.

5. Identifying the positive impacts of energy generation from different sources.

6. Identifying the negative impacts of energy generation from different sources.

7. Analysing the possible comparisons between the various energy generation methods including the nuclear method.

8. Providing a list of recommendations to deal with best economic energy generation policy.

9. Providing a list of recommendations to the decision makers in Egypt to increase the Gross Domestic Product (GDP) but adapting the best economic energy generation policy.

\section{Methodology}

The research work was a combination of a desk study and a field study. At the end of the field study, the data collected were sorted and analyzed in a statistical manner by using the SPSS statistical package. Then, the results were interpreted accordingly and in conjunction with the desk study. The research work comprised the following tasks:

\section{1- Desk study}

This included the following tasks:

1/1- Review the various economic, social and environmental literature discussing the problems of energy generation.

$1 / 2$ - Review the various relevant recent statistics.

$1 / 3$ - Review the role of the concerned governments in dealing with the energy generation process.

1/4- Review the role of the concerned governments in dealing with the various sources of energy.

\section{2- Field study and works}

The field study was conducted with the purpose of collecting primary data at several stages. The first stage dealt with the global energy data. The second stage dealt with the Egypt's energy data given by international sources. The third stage dealt with the Egypt's energy data given by the relevant domestic sources. 
This is in addition to an observation list that assisted in gathering data about the environmental performance of the various energy sources. The observation list also dealt with the specific relevant position of Egypt.

The data collection and interviews were done by the author who has relevant field experience in the Egyptian energy sector. He supervised a team of data collectors who were selected by the author to collect data and facilitate access to the required data.

The statistical work was done by using the SPSS package and the back-office work was carried out by an experienced assistant.

\section{Could New and Renewable Energy Sources Replace Traditional Fusel Fuel Energy Sources?}

New and renewable energy (including nuclear energy) application is subject to its relevant cost-benefit analysis. The story is complicated. To understand the complexity of the story, a life example is used in this connection. In 2014, a White House report written by Larry Summers, Ron Klain, and Carol Browner ${ }^{2}$ verified that the subsidies for wind energy generation projects are very high. The total government subsidies for the Shepherds Flats wind project totaled at USD 1.2 billion. The total costs reached USD 1.9 billion.

The government subsidies reached about $63 \%$ of the total costs of a Shepherds Flats wind project. Therefore, the sale price cannot be treated anymore as a true measure of cost. The US Government Accountability Office counted a total of 82 initiatives handled by 9 US federal agencies that supported the wind industry with direct and indirect subsidies.

To establish new wind energy generation projects and to compare it to the existing widespread traditional fusel fuel energy generation projects is completely unfair! The reason behind this is that the old existing traditional fusel fuel energy generation projects enjoy sunk costs. On the other hand, the new and renewable energy generation projects are facing very high current investment costs which make the unviable when compared in many occasions to the traditional fusel fuel energy generation projects. This is a very important point that many analysts and even institutions ignore when they make relevant comparisons in terms of the comparable cost and benefit analysis.

At this point in the critique, EIA (2104) proved by using world data that a MWh of wind energy has an average economic benefit of USD 64.60/MWh, which is still higher than the average economic cost of wind energy of below

\footnotetext{
${ }^{2}$ Summers, Larry; Ron Klain, \& Carol Browner, US Subsidies for Wind Projects, White House Report, Washington DC: The White House, 2104.
} 
USD 50/MWh. Accordingly, wind energy generation ultimately provides net positive benefits for consumers.

In spite of the fact that new and renewable energy generation is still viable, especially in the long run and within a social cost-benefit analysis framework, but we still have to utilize the existing widespread traditional fusel fuel power plants. ${ }^{3}$ Shutting down existing widespread traditional fusel fuel power plants before the end of their economic live cycles will entail very high costs, which will ultimately be reflected in a remarkable increase the cost of electricity. This applies all types of the replacement technology given by wind energy, natural gas energy, solar energy, or even nuclear energy.

Therefore, we may conclude at this part of this analysis that the world has no choice but to witness a relatively long transitional period with overlapping fusel fuel traditional polluting power plants and new and renewable environment friendly socially and economically viable power plants.

\section{Electricity Generation: Global Analysis}

According to the International Energy Statistics of the International Energy Data and Analysis, The U.S. Energy Information Administration (EIA)- the U.S. Department of Energy (DOE), 2015 (as indicated in Table 1 in Annex 1), China is the world biggest electricity producer with an amount of 4,768 Billion Kilowatt-hours. The USA is the world second biggest electricity producer with an amount of 4,768 Billion Kilowatt-hours.

Running the data of electricity generation by using the SPSS showed a weak correlation between electricity generation and the Gross Domestic Product (GDP) and the GDP per capita in one hand and with the number of the population in the other hand. For example, the electricity production of India is higher than that of Germany, and other G-8 countries that enjoy stronger economies. Also, the USA produces more electricity than India that has a higher number of populations.

Egypt is ranked as number 25 among other countries in Total Electricity Net Generation in 2012 with an amount of 155 Billion Kilowatt-hours. This is definitely a low level of production if compared to other developed countries and even to some other less developed (developing) countries, such as Saudi

3 Leutz, R., T. Ackermann, A. Suzuki, A. Akisawa, T. Kashiwagi, 2013, Technical offshore wind energy potentials around the globe, In: European Wind Energy Conference and Exhibition, Copenhagen, Denmark.

Fellows, A., 2012, The potential of wind energy to reduce carbon dioxide emissions, Glasgow, Garrad Hassan, pp: 146.

German Aerospace Center (DLR), 2015, Concentrating Solar Power for the Mediterranean Region, Institute of Technical Thermodynamics, pp 285. 
Arabia and Ukraine. This ultimately constitute an obstacle to the Egyptian endeavours to attain social and economic development as the biggest Arab economy in terms of population and industrial sector.

\section{The Economics of Nuclear Power}

The levelised actual costs of electricity generation measured in US cents/kWh for various sources of electricity are shown in the Table 2 in Annex 2 and as supported by Figure 1 in Annex 2.

This shows the levelised cost, which is the average cost of producing electricity including capital, finance, owner's costs on site, fuel and operation over a plant's lifetime.

The table shows that the nuclear electricity generation technology exhibited the lower average levelised costs as compared to the other electricity generation technology.

Accordingly, nuclear power is cost efficient if compared with the other forms of electricity generation, except if there is a direct access to low-cost fossil fuels.

Quiggin (2013), and Kee (2104) showed several world analyses that the fuel costs of nuclear power plants are still a minor proportion of the total generation costs.

However, investment costs of the nuclear power plants are greater than the investment costs of the coal-fired plants.

The investment costs of the nuclear power plants are much greater than the investment costs of the gas-fired plants.

Providing incentives for long-term, high-capital investment in deregulated markets is still a basic requirement in securing a diversified and reliable electricity supply system.

In assessing the economics of nuclear power, decommissioning and waste disposal costs are part of the cost structure of any nuclear power plant.

Also, the construction costs of the nuclear power plant together with the related large infrastructure costs are still very high if compared to the other forms of the power plants. This is what most nuclear energy economics literature verified.

The truth is slightly different. From my market survey stipulated in the observation list, it was found that the production of a nuclear power plant is very huge if compared to any other form of power plants. 
This justifies the large costs attributed to the nuclear power plants. This also justifies why the nuclear power plants has the lower average levelised costs as compared to the other electricity generation technology.

Institute for Energy Research (IER) (2015) verified that the main running cost component of a nuclear power plant is attributed to normal fuel cost and uranium price.

The use of normal fuel cost in a nuclear reactor is relatively small. Normal fuel costs are relatively stable over time in terms of their projection. On the other hand, the world uranium price witnessed a rise between 2003 and 2007 that added to the nuclear power generation costs, and then it stabilized in all following years. This helped the nuclear energy to have the lowest average operating costs.

\section{The Nuclear Power Programme of Egypt}

The data and the information collected in this part of analysis in this research paper is based on the observation list, the field work, and the information announced recently in the Egyptian TV and the Egyptian press.

The nuclear power programme of Egypt started in 1954 as the first research reactor ETRR-1 was built in cooperation with the former Soviet Union in 1958 at Inchass in the Nile Delta.

The Nuclear Power Plants Authority (NPPA) was established in 1976 under the supervision of the Egyptian Ministry of Electricity. The NPPA selected the El Dabaa site on the Mediterranean coast in 1983 to allow Egypt to enter into the peaceful nuclear power generation program as planned.

As shown in the Literature Review Egypt is an observer in the OPEC but still a full member in the OAPEC (Organization of Arab Petroleum Exporting Countries). Also, Egypt has the third largest proved natural gas reserves in Africa.

Also, Egypt has the biggest existing hydroelectric power generation in Africa in the Aswan Dam since the end of the 1950s. In the field of renewable energy, Egypt has established wind and solar energy stations.

Egypt is planning to build wind and solar energy power plants within the coming three years to generate around 4,300 megawatts of power.

Also, Egypt recently discovered in 2015 a large reserve of natural gas off the Mediterranean coast. This off shore new well was in cooperation with an Italian company. It is expected strongly boost the Egyptian production and reserves of natural gas, and hence of liquefied natural gas. 
Egypt is still embarking its new nuclear energy projects to generate electricity. Egypt is targeting a diversification in the sources of energy, as well as securing sustainability in energy generation.

On Thursday, 19 November, 2015 the Egyptian TV followed by press release in all Egyptian newspapers announced that Egypt and Russia signed an agreement to build the first Egyptian nuclear power plant in El Dabaa site on the Mediterranean coast to be completed by 2022 .

The new nuclear power plant is a very advanced and highly secured 'thirdgeneration' plant which consists of four reactors. This new nuclear power plant in El Dabaa will capable to cover the Egypt's increasing future demand for electric energy.

Russia signed a separate agreement with Egypt to provide a loan to be paid off over 35 years to finance the new nuclear power plant project.

The project is considered to be self financed as related to the repayment of the loan. The government of Egypt (GOE) will not bear the cost of building this new nuclear power plant. The cost will be paid back through the actual production of electricity that will be generated by this new nuclear power plant.

Russia has a significant experience that will share it with Egypt. The construction of the new nuclear power plant in El Dabaa will open the gate for the creation of a whole new nuclear power industry in Egypt.

This will definitely result in the advancement of the Egyptian industries, and will have positive impacts on the Egyptian exports. On the other hand, Egypt will build new expertise in a new high tech field.

This will promote the Egyptian educational and training sectors. This will also increase the Egyptian export of knowhow and skilled labour. Egyptian workers' remittances constitute a major source of foreign currency required for Egypt's reserves of foreign currencies. Again, Egypt's suitable reserve of foreign currencies is one of the requirements to maintain and to promote the stable economic performance.

The new nuclear power plant in El Dabaa will be established over $55 \mathrm{~km}^{2}$ which requires infrastructure in addition to 1,500 houses to serve tribal residents who used to live in the site area. 


\section{Conclusion and Recommendations}

The findings of the data collected at both the global level and at Egypt's level represented the various energy resources at a comparative level.

The findings typified the need of Egypt to increase its relatively low production of electricity energy to match with its development requirements. This could never be done without the use of nuclear energy to produce electricity energy to serve the various Egyptian economic sectors.

The data collected all through the research paper were sorted and analyzed in a statistical manner to analyze the Egyptian requirement of energy in general and nuclear energy in specific for economic development.

The findings presented above illustrate the interaction between the diversification of the sources of energy and the requirements to achieve sustainable economic development.

It is, therefore, recommended that the following should be applied:

1. Egypt needs to diversify its energy sources.

2. Egypt needs to utilize extensively the low cost energy sources, such as building wind plants in the best worldwide wind energy site in Zafarana in the Red Sea.

3. Egypt needs to build several cost effective advanced nuclear power plants. El Dabaa should be the beginning.

4. Egypt needs to develop special infrastructure to match with the new energy generation projects.

5. Egypt needs to use these new energy generation projects to establish new communities next to the new sites. The new communities will have mutual benefits with the new projects.

6. Egypt needs to introduce new industries to serve the new power generation projects.

7. Egypt needs to make use of these new technologies to reintroduce itself as a technology provider at least at a regional level. This will help Egypt to open new formulas of business and cooperation with the Arab and African countries as a regional superpower. 


\section{References}

1. ASES, 2014, Tackling Climate Change in the U.S. Potential Carbon Emissions Reductions from Energy Efficiency and Renewable Energy Emissions Reductions by 2030, Ed. Kutscher, C.F. pp 14.

2. Bartle A., 2012, Hydropower potential and development activities, Energy Policy, 30, pp. 1231-1239

3. Berndes, G., M. Hoogwijk, R. van den Broek, 2013, The contribution of biomass in the future global energy system: a review of 17 studies, Biomass and Bioenergy, 25(1), pp: 1 - 28.

4. Bjornsson, J. Fridleifsson .B., Helgason, T. Jonatansson, H. Mariusson, J. Palmason, G Stefansson, V Thorsteinsson, L, 2104, The Potential Role of Geothermal Energy and Hydropower in the World Energy Scenario in Year 2020, pp 18.

5. Bradley, Matt (2013). "Apache hopeful shale drilling takes off in Egypt Stories". Market Watch. Retrieved June 18, 2013.

6. Dessus, B., B. Devin, F. Pharabob, 2104, World potential of renewable energies, Paris, CNRS - PIRSEM, pp: 70.

7. Vries, B. de, D. van Vuuren, M. M. Hoogwijk, 2007, Renewable energy sources: Their global potential for the first-half 21 st century at a global level: An integrated approach. Energy Policy 35 (2007) 2590-2610.

8. Doornbosch, R. and R. Steenblik, 2009, Biofuels is the cure worse than the disease? OECD Roundtable on Sustainable Development. Paris, 11-12 September 2007.

9. EEA, 2006, How much bioenergy can Europe produce without harming the environment?, EEA, Copenhagen, Report number 7/2006, pp 72.

10. EIA (2014), "Technically Recoverable Shale Oil, Shale Gas and Wind Resources: An Assessment of 137 Shale Formations in 41 Countries Outside the United States" (PDF). U.S. Energy Information Administration (EIA). June 2014. Retrieved June 11, 2014.

11. Ericsson K., L. Nilsson, 2013, Assessment of the potential biomass supply in Europe using a resource-focused approach, Biomass and Bioenergy, 30 pp $1-15$.

12. FAO/RWEDP, 2010, Biomass energy in ASEAN Member Countries, pp 20.

13. Fellows, A., 2012, The potential of wind energy to reduce carbon dioxide emissions, Glasgow, Garrad Hassan, pp: 146.

14. Fischer, G. and L. Schrattenholzer, 2010, Global bioenergy potentials through 2050, Biomass and Bioenergy, 20(3), pp: 151 - 159.

15. Fridleifson, I.B., 2011, Geothermal energy for the benefit of the people, Renewable and Sustainable Energy Reviews 5 pp 299-312

16. Gallagher P., M. Dikeman, J. Fritz, E. Wailes, W. Gauther, H. Shapouri, 
17.2003, Biomass from Crop Residues: Cost and Supply Estimates, U.S. Department of Agriculture, Office of the Chief Economist, Office of Energy, Policy and New Uses. Agricultural Economic Report No. 819, pp 30

18. German Aerospace Center (DLR), 2015, Concentrating Solar Power for the Mediterranean Region, Institute of Technical Thermodynamics, pp 285.

19. Greenpeace, EREC, 2007: Energy Revolution: a Sustainable World Energy Outlook-Global Report. Brussels: EREC 43

20. Hall, D. O., F. Rosillo-Calle, R. H Williams, J. Woods, 1993, Biomass for energy: supply prospects, In: Renewable energy: Sources for fuels and electricity, Eds: T.B.Johansson, H. Kelly, A. K. N. Reddy and R. H. Williams, Washington, Island Press, pp: 1160.

21. Hofman, Y., D. de Jager, E. Molenbroek, F. Schilig, M. Voogt, 2012, The potential of solar electricity to reduce $\mathrm{CO} 2$ emissions, Utrecht, Ecofys, pp: 106.

22. Hoogwijk, M., B. de vries, W. Turkenburg, 2014, Assessment of the global and regional geographical, technical and economic potential of onshore wind energy. Energy Economics 26 (2004) 889-919.

23. Hoogwijk M., A. Faaij, R. van den Broek, G. Berndes, D. Gielen, W. Turkenburg,2003, Exploration of the ranges of the global potential of biomass for energy, Biomass and Bioenergy, 25, pp. $119-133$

24. Hoogwijk M., A. Faaij, B. de Vries, W. Turkenburg, 2014, The potential of biomass energy under four land-use scenarios. Part B: exploration of regional and global cost-supply curves.

25. Hoogwijk M., 2004, On the Global and Regional Potential of Renewable Energy Sources, Utrecht University, Department of Science, Technology and Society, pp 256.

26. IEA, 2005, Energy Technology Perspective, IEA/OECD, Paris.

27. IEA, 2005b, Offshore wind Experiences, technical Paper, Paris, pp 54.

28. IEA, 2006, World Energy Outlook 2006, IEA/OECD, Paris.

29. Institute for Energy Research (IER) (2015) The Levelized Cost of Electricity from Existing Generation Resources Report, July, 2015.

30. International Geothermal Association, 2007, data available at:

31.http://iga.igg.cnr.it/geoworld/geoworld.php

32. IPCC, 2007. Climate change 2007: Mitigation. Contribution of Working group III to the Fourth Assessment Report of the Intergovernmental Panel on Climate Change, B. Metz, O. R. Davidson, P. R. Bosch, R. Dave, L. A. Meyer (eds), Cambridge University Press, Cambridge, United Kingdom and New York, NY, USA.

33. Quiggin, John (8 November 2013). "Reviving nuclear power debates is a distraction. We need to use less energy". The Guardian. 
34. Johansson, T. B., H. Kelly, A. K. N. Reddy and R. H. Williams, 2013, Renewable fuels and electricity for a growing world economy. Defining and achieving the potential, In: Renewable energy: Sources for fuels and electricity, Eds: T. B. Johansson, H. Kelly, A. K. N. Reddy and R. H. Williams. Washington, D.C., Island Press, pp: 1 - 71.

35. Johansson T., K.McCormick , L. Neij W. Turkenburg, 2004, The Potentials of Renewable Energy- Thematic Background Paper, available at: www.renewables2004.de, pp 40.

36. Kee, Edward (21014). "Future of Nuclear Energy" (PDF). NERA Economic Consulting. 2 October 2013.

37. Lako P., H. Eder, M. de Noord, H. Reisinger, 2013, Hydropower development with a focus on Asia and Western Europe, ECN/Verbundplan, pp 96.

38. Lehner B., G. Czisch, S. Vassolo, 2005, The impact of global change on the hydropower potential of Europe: a model-based analysis, Energy Policy, 33, pp 839 - 855

39. Leutz, R., T. Ackermann, A. Suzuki, A. Akisawa, T. Kashiwagi, 2013, Technical offshore wind energy potentials around the globe, In: European Wind Energy Conference and Exhibition, Copenhagen, Denmark.

40. Milbrandt A., 2005,A Geographic Perspective on the Current Biomass Resource Availability in the United States, pp 70

41. Molenbroek E., and E. de Visser, Elektriciteit uit geconcentreerde zoneenergie op korte termijn, Ecofys, 2006 pp44

42. NEA/IEA/OECD, 2005, Projected Costs of Generating Electricity, 2005 Update, pp 230.

43. Pelc, R. and R.M. Fujita, 2012, Renewable energy from the ocean, Marine Policy 26 pp 471-479.

44. Price, L. \& S. de la Rue du Can, 2006, Sectoral trends in global energy use and greenhouse gas emissions, Lawrence Berkeley Laboratory, LBNL56144.

45. Ragwitz M., C. Huber, G. Resch, S. White, 2013, Dynamic cost-resource curves - Work Package 1, FhG-ISI, EEG, IT Power, pp. 186.

46. REN21, 2013, Renewable Energy Status Report, REN 21, Ed. Eric Martinot, pp 35.

47. Siemons R., M. Vis, D.van den Berg I.Mc Chesney, M. Whiteley N. Nikolaou, 2004, Bioenergy's role in the EU energy market - A view of developments until 2020 BTG, ESD, CRES, pp 270

48. Siegfriedsen S., M. Lehnhoff, A. Prehn, 2014, Offshore Wind Energy Potential Outside the European Union, aerodyn Engineering GmbH, pp 13

49. Smeets E, and A. Faaij, 2006, Bioenergy Potentials from Forestry in 2050. An assessment of the drivers that determine the potentials. Climatic Change (in press). 
50. Stefánsson V. and I. B. Fridleifsson, 1998, Geothermal Energy European and worldwide perspective, Presented at Expert hearing on "Assessments and Prospects for Geothermal Energy in Europe" in the framework of SubCommittee on Technology Policy and Energy of the Parliamentary Assembly of the Council of Europe, 12 May 1998, Strasbourg.

51. Summers, Larry; Ron Klain, \& Carol Browner, 2104, US Subsidies for Wind Projects, White House Report, Washington DC: The White House.

52. Tampier, M, 2004, Renewable Energy Potentials in Canada, presentation for Commission for Environmental Cooperation Building the Renewable Energy Market in North America, 28 - 29 October 2004

53. UNDP/WEC, World Energy Assessment, Ed: J.Goldemberg, Washington D.C., UNDP, 2010

54. U.S. Department of the Interior, 2006, Technology White Paper on Wave Energy Potential on the U.S. Outer Continental Shelf, pp 12.

55. USDA/USDOE, 2015, Biomass as feedstock for a Bioenergy and Bioproducts Industry: The technical feasibility of a Billion-ton Annual Supply, pp 78

56. Van Dam, J., A. Faaij, I. Lewandowski, G. Fisher, 2007, Biomass production potentials in Central and Eastern Europe under different scenarios, Biomass and Bioenergy 31, pp 345-366

57. Williams, R. H., 1995, Variants of a low CO2 -emitting energy supply system (LESS) for the world - prepared for the IPCC Second Assessment Report Working Group IIa, Energy Supply Mitigation Options, Richland, Pacific Northwest Laboratories, pp: 39.

58. World Energy Council, 1994, New renewable energy resources. A guide to the future, London, Kogan Page Limited.

59. World Energy Council, 2013, Survey of Renewable Energy Sources, available online at:

60. http://212.125.77.15/wec-geis/publications/reports/ser/overview.asp

61. Van Hulle, S. le Bot, Y. Cabooter, J. Soens, V. Van Lancker, S. Deleu, J.P. Henriet, G. Palmers, L. Dewilde, J. Driesen, P. Van Roy, R. Belmans, "optimal offshore wind energy developments in Belgium, 2004, pp, 154.

62. Yamamoto, H., J. Fujino, K. Yamaji, 2010, Evaluation of bioenergy potential with a multi-regional global-land-use-and-energy model, Biomass and Bioenergy, 21, pp: 185 - 203.

63. Younes, Mohamed Abdel-Aziz (2013). Mohamed Abdel-Aziz Younes, ed. Crude Oil Exploration in the World (hardcover or pdf). InTech. pp. Chapter 2, "Hydrocarbon Potentials in the Northern Western Desert of Egypt". ISBN 978-953-51-0379-0. Retrieved June 14, 2013. 
Annexes

Annex 1

Table 1: Total Electricity Net Generation for the Top 60 Ranked Countries, 2014

\begin{tabular}{|c|c|c|}
\hline Rank & Country & Billion Kilowatt-hours \\
\hline 1 & China & 4768 \\
\hline 2 & United States & 4048 \\
\hline 3 & India & 1052 \\
\hline 4 & Russia & 1012 \\
\hline 5 & Japan & 966 \\
\hline 6 & Canada & 616 \\
\hline 7 & Germany & 585 \\
\hline 8 & Brazil & 538 \\
\hline 9 & France & 533 \\
\hline 10 & Korea, South & 500 \\
\hline 11 & United Kingdom & 336 \\
\hline 12 & Italy & 281 \\
\hline 13 & Spain & 280 \\
\hline 14 & Mexico & 279 \\
\hline 15 & Saudi Arabia & 255 \\
\hline 16 & Iran & 239 \\
\hline 17 & South Africa & 239 \\
\hline 18 & Australia & 235 \\
\hline 19 & Taiwan & 234 \\
\hline
\end{tabular}




\begin{tabular}{|c|c|c|}
\hline 20 & Turkey & 228 \\
\hline 21 & Ukraine & 187 \\
\hline 22 & Indonesia & 185 \\
\hline 23 & Sweden & 161 \\
\hline 24 & Thailand & 156 \\
\hline 25 & Egypt & 155 \\
\hline 26 & Poland & 153 \\
\hline 27 & Norway & 145 \\
\hline 28 & Argentina & 128 \\
\hline 29 & Malaysia & 127 \\
\hline 30 & Venezuela & 123 \\
\hline 31 & Vietnam & 118 \\
\hline 32 & United Arab Emirates & 101 \\
\hline 33 & Netherlands & 95 \\
\hline 34 & Pakistan & 93 \\
\hline 35 & Kazakhstan & 86 \\
\hline 36 & Czech Republic & 82 \\
\hline 37 & Belgium & 76 \\
\hline 38 & Philippines & 70 \\
\hline 39 & Finland & 68 \\
\hline 40 & Chile & 67 \\
\hline 41 & Austria & 65 \\
\hline 42 & Switzerland & 65 \\
\hline
\end{tabular}




\begin{tabular}{|c|c|c|}
\hline 43 & Paraguay & 60 \\
\hline 44 & Israel & 59 \\
\hline 44 & Kuwait & 59 \\
\hline 46 & Colombia & 58 \\
\hline 46 & Greece & 58 \\
\hline 46 & Iraq & 58 \\
\hline 49 & Romania & 56 \\
\hline 50 & Algeria & 54 \\
\hline 51 & Bulgaria & 44 \\
\hline 52 & New Zealand & 43 \\
\hline 52 & Portugal & 43 \\
\hline 53 & Peru & 39 \\
\hline 54 & Hong Kong & 37 \\
\hline 55 & Qatar & 33 \\
\hline 56 & Hungary & 32 \\
\hline 56 & Libya & 32 \\
\hline 56 & Serbia & 32 \\
\hline 57 & Belarus & 29 \\
\hline 57 & Denmark & 29 \\
\hline 57 & Syria & 29 \\
\hline 58 & Nigeria & 27 \\
\hline 58 & Slovakia & 27 \\
\hline 59 & Ireland & 26 \\
\hline 60 & Morocco & 25 \\
\hline
\end{tabular}

Source: International Energy Statistics: International Energy Data and Analysis, The U.S. Energy Information Administration (EIA)- the U.S. Department of Energy (DOE), 2015 


\section{Annex 2}

Table 2: Actual Costs of Electricity (US cents/kWh)

\begin{tabular}{|c|c|c|c|}
\hline Technology & $\begin{array}{l}\text { region or } \\
\text { country }\end{array}$ & $\begin{array}{l}\text { At } 10 \% \text { discount } \\
\text { rate }\end{array}$ & $\begin{array}{l}\text { At 5\% discount } \\
\text { rate }\end{array}$ \\
\hline \multirow[t]{2}{*}{ Nuclear } & OECD Europe & $8.3-13.7$ & $5.0-8.2$ \\
\hline & China & $4.4-5.5$ & $3.0-3.6$ \\
\hline $\begin{array}{l}\text { Black coal with } \\
\text { CCS }\end{array}$ & OECD Europe & 11.0 & 8.5 \\
\hline $\begin{array}{l}\text { Brown coal with } \\
\text { CCS }\end{array}$ & OECD Europe & $9.5-14.3$ & $6.8-9.3$ \\
\hline CCGT with CCS & OECD Europe & 11.8 & 9.8 \\
\hline \multirow[t]{3}{*}{$\begin{array}{l}\text { Large hydro- } \\
\text { electric }\end{array}$} & OECD Europe & $14.0-45.9$ & $7.4-23.1$ \\
\hline & China: 3 Gorges & 5.2 & 2.9 \\
\hline & China: other & $2.3-3.3$ & $1.2-1.7$ \\
\hline \multirow[t]{2}{*}{ Onshore wind } & OECD Europe & $12.2-23.0$ & $9.0-14.6$ \\
\hline & China & $7.2-12.6$ & $5.1-8.9$ \\
\hline Offshore wind & OECD Europe & $18.7-26.1$ & $13.8-18.8$ \\
\hline \multirow[t]{2}{*}{$\begin{array}{l}\text { Solar } \\
\text { photovoltaic }\end{array}$} & OECD Europe & $38.8-61.6$ & $28.7-41.0$ \\
\hline & China & $18.7-28.3$ & $12.3-18.6$ \\
\hline
\end{tabular}

Source: OECD/IEA-NEA, 2010, Projected Costs of Generating Electricity, Tables 3.7

\section{Figure 1: US Electricity Production Costs}

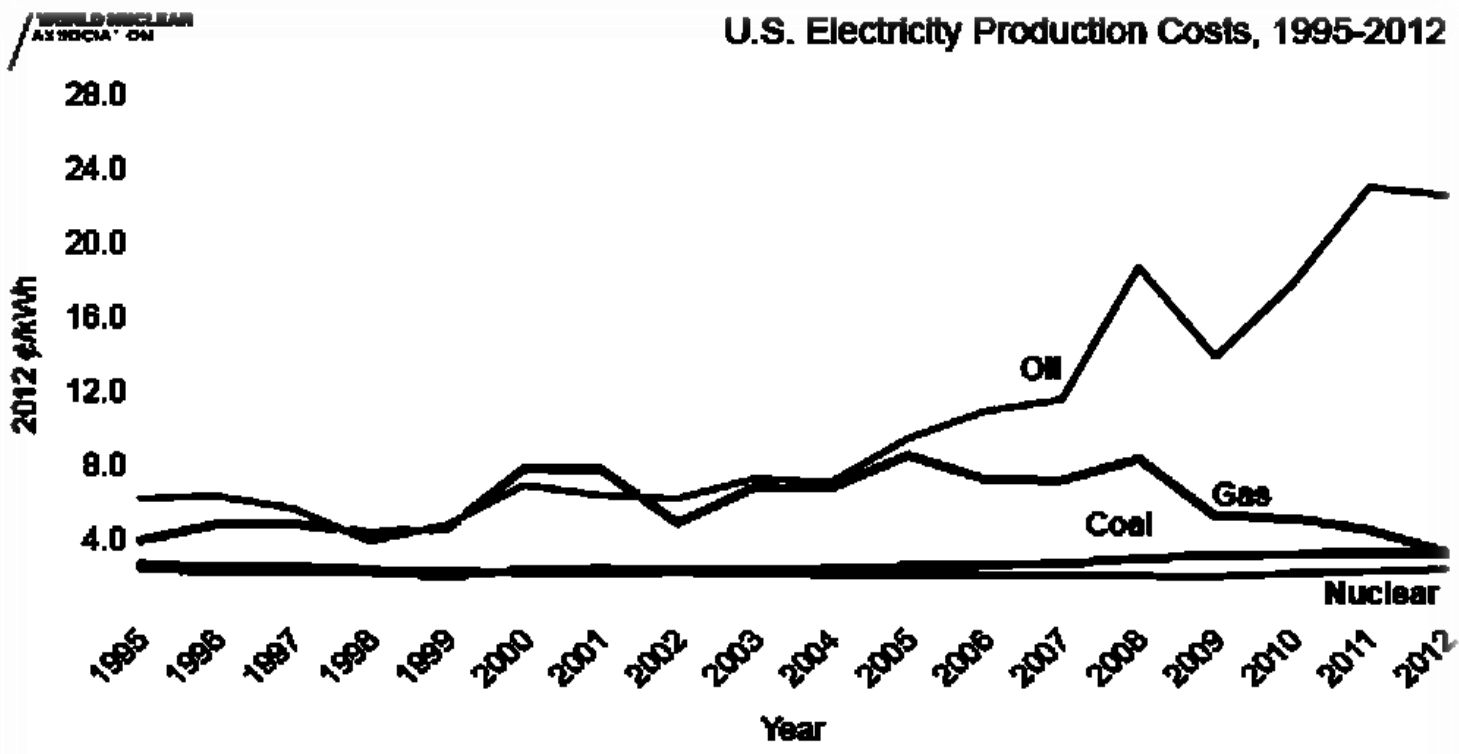

Production costs $=$ operation \& mainienance + fuel. (excludes indirect costs and capital) Source: Ventyx Velocity Suite / NEI, May 2013 